\title{
An Evaluation of the Nature of Public Spaces in the Private Realm over the Examples of Privately Owned Public Spaces in NYC
}

\author{
Tuğçe Ertan \\ Izmir Katip Celebi University \\ Hamit Gokay Meric \\ Izmir Katip Celebi University
}

\begin{abstract}
The designing and implementation of public spaces have a crucial role in the development of cities. A city's success is generally based on the quality of its public spaces and it is a fact that public space is an elementary aspect of urban life. Moreover, one mandatory standard for big cities to function well is there to be a welcoming public space, where a number of urban activities can take place. According to the general notion, parks, streets, city squares, sidewalks, etc. can be included in public spaces. In addition to these, some indoor spaces such as below ground stories, plaza entrances and places like waterfronts or elevated structures with new functions have been considered as public space nowadays. In order to create, design and finance public spaces, sometimes private organizations and public governmental bodies cooperate. However, a game changer in the public and private realm was the 1961 zoning program of New York City Department of City Planning. This program gave permission to private developers build more floor space than they were allowed in exchange for supplying public spaces. As a result of this act, privately owned public spaces (POPS) were created blurring the definition of public space. Today there are more than five hundred POPS in NYC including indoor and outdoor spaces. This study will try to provide an analysis and general view of POPS as public spaces questioning the issues about their use, control and ownership. The criteria of successful urban design for public spaces and the role of governmental authorities in regulating and planning the public spaces will be discussed along with the boundaries and scope of public activities that can take place in public spaces. Finally, the question of whether the ownership of public space by private harms the concept of public space and the rights of citizens will be approached via different perspectives. After looking at the conceptual definitions of public space in literature and analyzing specific examples of POPS, this paper will attempt to come up with a functioning definition of public space in the private realm.
\end{abstract}

Keywords: public space, new york city, privately owned public spaces, urban planning

\section{Introduction}

Individuals of a city use public space to gather, interact with each other and to simply be and express themselves. Since before the time of the Greek Agora city life has in many ways been defined by its public space (Wilshire, 2012). Due to political and economic benefits, these public spaces are in a delicate position of privatization, which can lead to the end of public space as we know it. Public spaces are symbolic "places" that can be scenes for conflict between contradicting actors or stages of marketing for the business sector. Especially after globalization has accelerated, big cities are facing the consequences of privatization of public space due to their increasing population and economic significance as well as being a political platform.

New York City, being the capital of world financial markets, is one of the biggest and most important metropolises of the world. Consequently, it has also been a city that was majorly affected by the privatization of public space. In 1961, the zoning plan gave permission to land owners and developers to build more floors in exchange of providing public space in their own property for the public. Blurring the limits and the definition of public space, the questions of who these public spaces are for and whether they are venues for free speech or just a landscape for specified people were raised. Occupy 
Wall Street in Zuccotti Park in 2011 was a reflection of this confusion and it was a demonstration of how these privately owned public spaces (POPS) can actually be used by random people, that it wasn't originally intended for corporate people only.

The privatization of public spaces is a controversial issue and this paper will be examining the situation by discussing specific examples of privately owned public spaces in NYC and try to understand if this system is actually working.

\section{Public Space}

In order to discuss the current issues about the topic it is important to understand what public space is. Space points out to a more abstract area defined only by physical means whereas place gives a meaning to space in the context of social and economic purposes as well as ownership matters. Public space, on the other hand, is a completely different concept. It is a "place" where the community can access no matter what their gender, economic class or race is. They are for everybody and they are also venues of free speech, protest, social interaction and spontaneous activities. "In the parks, plazas, markets, waterfronts, and natural areas of our cities, people from different cultural groups can come together in a supportive context of mutual enjoyment. As these experiences are repeated, public spaces become vessels to carry positive communal meanings" (Carr, Francis, Rivlin and Stone, 1992). A space cannot be considered public unless it is generally occupied by the community members (Kimmelman, 2012).

Public and private spaces co-exist rather than having very definite boundaries with each other. They have different levels of accessibilities and they usually do intersect. It is very uncommon that a space is either private or public but generally interfered physically and politically. From this perspective, the ownership and property issue raises: who owns and determines how resources are used, and what then is truly public? (Gieseking, Mangold, Katz, Low, \& Saegert, 2014). Mitchell mentions "the right to inhabit", as the sum of diverse ways an individual or a group can occupy a public space, is an essential human right (Purcell, 2003). In this context, public should be perceived within the concept of commons, resources which are available to all community members (Blackmar, 2006).

City parks, squares, plazas, market areas, piers, areas within public buildings, airports, some lobbies, etc. are some examples of public spaces. Nevertheless, the concept of public space has evolved and changed in the second half of $20^{\text {th }}$ century due to private-public cooperation. POPS is an example to this. As a matter of fact, it wouldn't be such a wrong action to say that public spaces are transforming into private spaces. Cities are malleable, pliable, and constantly changing, and as such the experience we have of urban spaces is always a negotiation between various powers and influences (Gieseking, Mangold, Katz, Low, \& Saegert, 2014).

\section{Privatization of Public Spaces}

The reason behind privatizing the public spaces is mostly economic. Providing public space can be an economic burden on public authorities, which they cannot always fulfill. Besides, the private organizations cherish the chance to get more income and have some control over urban space. In 1970's, the idea of private sector contributing to public institutions became a popular answer to the incompetency of public authorities in the name of creating more efficiency. It was a winwin solution.

One of the consequences of this approach was the private sector having a bigger act in society. In this way, private organizations gained high social reputation by contributing to public. Socially responsible commitments draw more people's attention as this is a popular issue in the modern age. Giving back to community by creating a public space attached to business structures bring more consumers to these organizations. Additionally, they are also given the opportunity to expand their use of land such as building more floors. If this trend continues, it will eradicate the last remaining spaces for democratic practices, places where a wide variety of people from different gender, class, culture, nationality and ethnicity intermingle peacefully (Low, Taplin and Scheld, 2005).

New York City has the biggest urban area in the US with its metropolitan area and almost twenty million population and it is the leading city of United States. Therefore, it sets an example with its public space privatization moves to other cities not only in the US but in the world. 


\section{Privately Owned Public Spaces in New York City}

New York City has limited funds for improving its public spaces as well and the regulations encourage the private organizations to get involved in privatizing public spaces. In 1961, NYC zoning plan granted the permission to build $20 \%$ more to developers who promised a contribution of creating a public space. The developers gained even more floor area depending on their contributions. For example, an indoor public space gave 12:1, meaning that the developer had the right to build twelve times the indoor public space he provided.

These privately owned public spaces, POPS, had some criteria according to the law. The developers had to create public spaces with useful and aesthetic utilities such as plants, benches, tables, etc. for public use. POPS are generally located in urban areas that are crowded and dense by buildings for the purpose of maintaining breathing space, air, greens and light to the residents. The Department of City Planning set some design rules for POPS such as being welcoming and inviting, accessible and giving the message of openness to public, safe, well-lit, comfortable and having seats. NYC has 530 privately owned public spaces in various forms such as sidewalks, arcades, urban plazas, parks, etc. adding up to more than three million square feet (Dimmer, 2013).

As a result, a huge number of public spaces were created mostly in Manhattan but the quality of these places is not so good. Some of them are being actively used but some of them are inaccessible or unusable. $16 \%$ of these POPS are actively used, $21 \%$ are simple resting places, $18 \%$ are circulation bound but $41 \%$ of POPS in NYC are in an unusable condition (Helleman, 2016). Thanks to Harvard Professor Jerold S. Kayden, all of these privately owned public spaces are spotted, presented and evaluated in his book of "Privately Owned Public Space: New York City Experience" (Privately Owned Public Spaces, 2007). This way, the public will be more aware of what they own as a public space and the owners will be more in the light to pursue their responsibilities. Later in 2002, Mr. Kayden established APOPS (Advocates of Privately Owned Public Spaces) and is working with NYC Department of City Planning and The Municipal Art Society of New York to activate POPS.

\section{Zuccotti Park}

Zuccotti Park is a POPS in Lower Manhattan. In fact it was once known as Liberty Plaza Park and it was the result of an agreement between New York City and US Steel in 1968. US Steel provided this park to public in memory of the protests in 1770's against UK taxes for tea in exchange of more floors for its building, One Liberty Plaza. However, in the 9/11 incident, the park was badly damaged but thanks to John Zuccotti, the chairman of the company who owns the land, pioneered a fundraising for the renewal of the park. After that, the park's name was changed to Zuccotti Park.

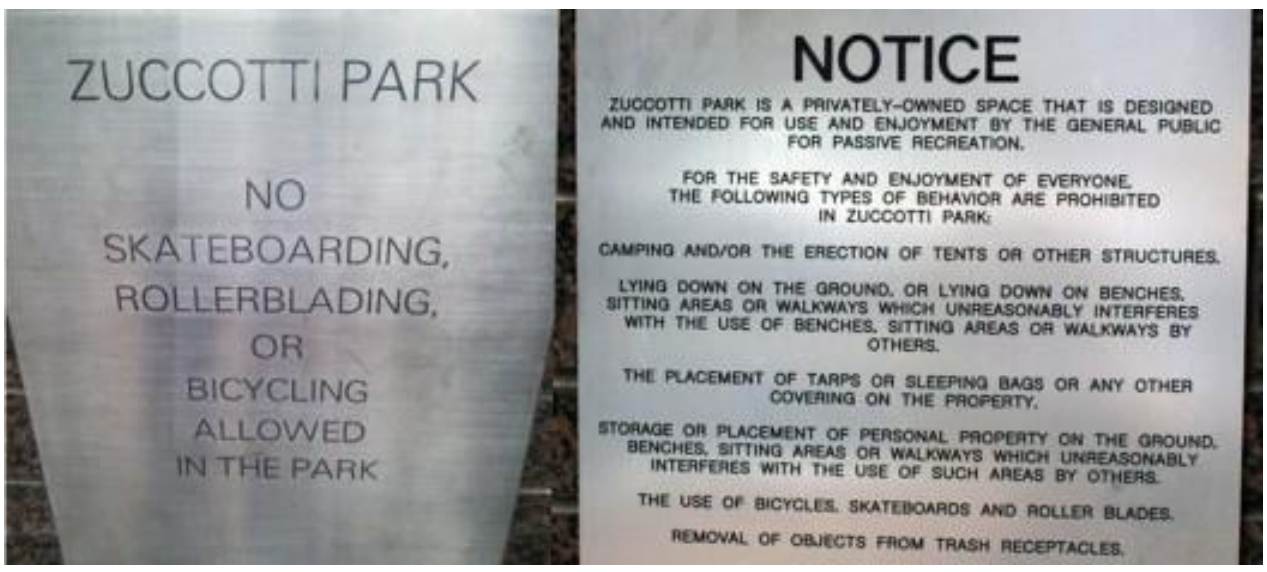

Figure 1 Zucotti Park Restrictions (Woodward, 2012).

In September 2011, the park was used as the base for protests of Occupy Wall Street due to its closeness to New York stock exchange and it being actually a public space. The protesters symbolically wanted to reclaim the name "liberty" in the park in opposition of its name after a businessman. Fitting the scene, Occupy Wall Street was a protest against capitalism 
and inequity with the slogan of "We are the 99\%" regarding the economic system that only benefits the richest $1 \%$. The protesters stayed in the park constantly for almost a month and police had no chance of interfering because it was a public park which had to be open 24 hours a day. Occupy also called attention to the co-opting of the public commons by the moneyed individuals and groups (Ulam, 2013).

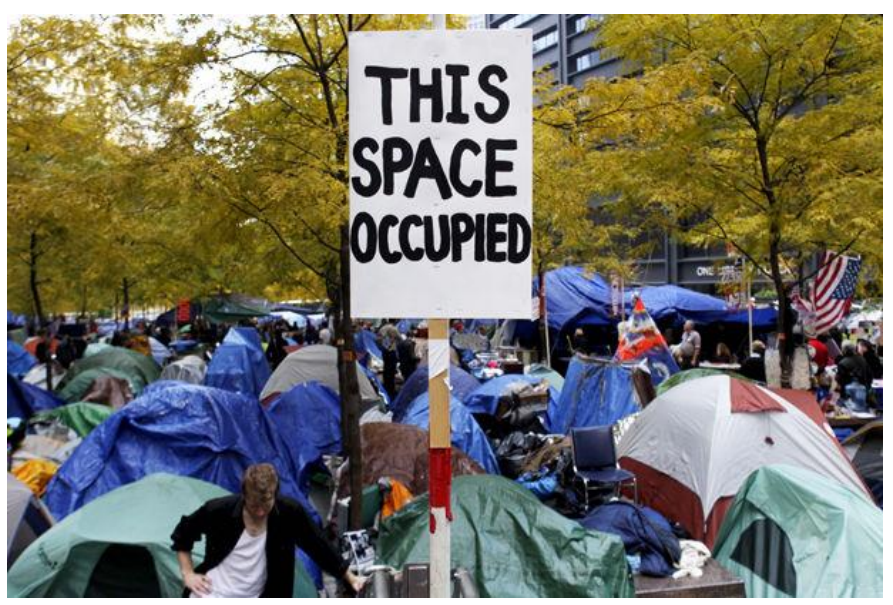

Figure 2. Occupy Wall Street (Helleman, 2016).

In October, owner of the park, Brookfield Properties, claimed that the park needed to be sanitized in spite of protesters cleaning the park every day and giving access to pedestrians. Continuous arguments of Brookfield Properties saying that the park was threatened led to the forcible eviction of protesters by NYPD on November $15^{\text {th }}$. Even though the protesters were legally allowed to return to Zuccotti Park after the cleaning, New York Supreme Court didn't let them back and the park was closed until January 2012.

\section{Trump Tower in Manhattan}

With the 1961 zoning plan in NYC, the developer of Trump Tower had the privilege of adding twenty extra floors to the building in exchange of a public atrium with a bench, restrooms and two upper-level public gardens. Twenty floors are almost the one third of the building equaling to more than $\$ 500$ million today (Chaban, 2015).

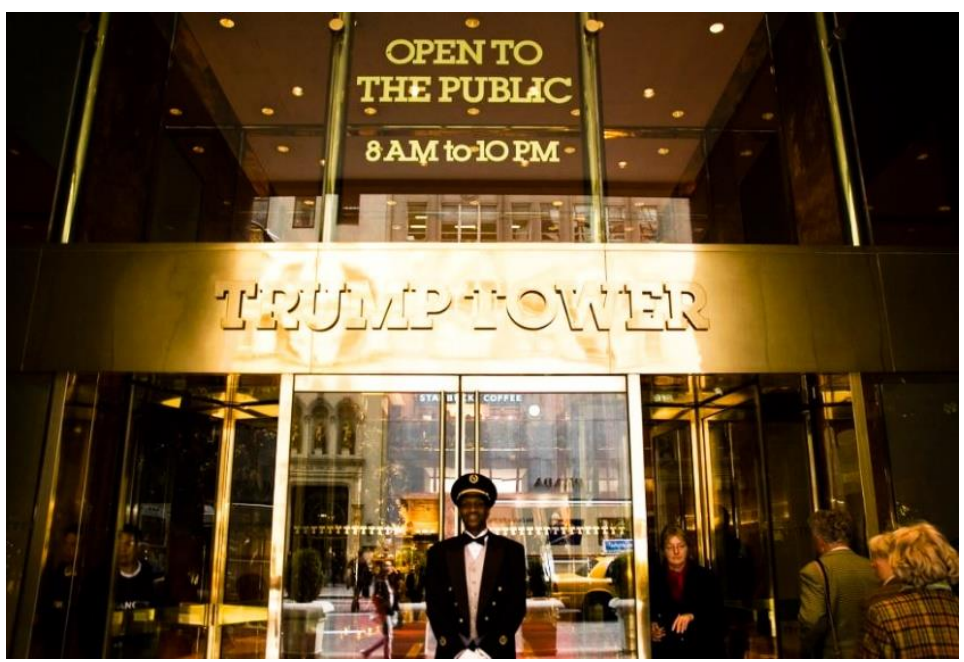


Figure 3. Trump Tower (Mahony, 2016).

Nevertheless, the agreement was breached many times until now. The main issue was mostly the promised bench in the atrium, sometimes disappearing and sometimes mysteriously being replaced. In 1983, when Trump Tower was opened, the bench was in the atrium but it was covered with planters and in a situation that couldn't be used. Trump explained the situation to the Department of City Planning as: "We have had tremendous difficulties with respect to the bench-drug addicts, vagrants, et cetera have come to the atrium in large numbers. Additionally, all sorts of 'horrors' had been taking place that effectively ruined the beautiful ambience of the space which everyone loves so much. " Later on, the planters were removed anyways due to the POPS agreement (Rosenberger, 2016)

In the coming years, the agreement was breached again resulting in fines from the department of city planning. In July 2016, the bench disappeared again and Trump Tower Commercial LLC had to pay a fine of $\$ 10.000$ for not showing up in the court regarding the case of the bench. Later in August 2016, new metal benches were placed in the atrium but they still had to pay the fine due to their prior violation. However, the corporation neglected the agreement and inserted large counters of Trump Merchandise sellers into the atrium resulting in a $\$ 4000$ fine by the city (Mahony, 2016).
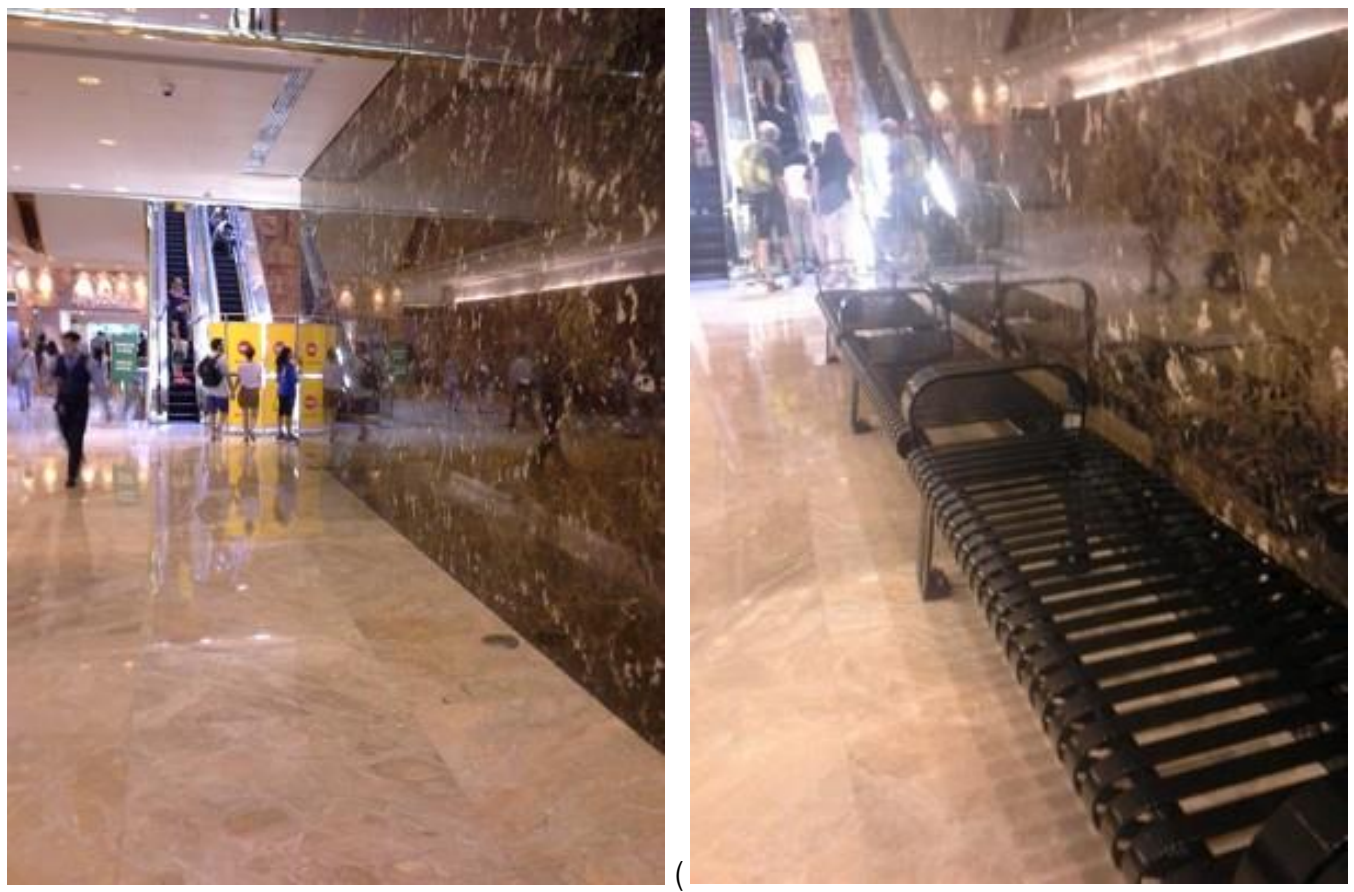

Figure 4\&5. Trump Tower Atrium With/Without Bench (Rosenberger, 2016).

Other POPS in Trump Tower are not functioning properly as well. There are reports of users stating that guards of Trump Tower are discouraging people to enter public gardens on the fourth and fifth floor. Despite the well-observed signs of Trump Ice Cream Parlor, Trump Grill and Trump Store, the signs to these POPS gardens are not very visible. Sometimes the gardens deny access with a velvet rope for no reason or when they are open, they lack the required tables and the agreed trees in the gardens are almost dead (Rosenberger, 2016).

Additionally, Trump uses the public atrium improperly for his press conferences and campaign rallies from time to time but the agreement of POPS in 1970's indicates that the atrium can only be used four times a year with a prior permission from the city. The Trump Organization made an explanation to The Wall Street Journal about this issue stating that there is no such agreement to limit the use of the atrium as Trump pleases (Mahony, 2016). According to Kayden, these kinds of 
violations of POPS agreements such as denial of access, implementation of sales counters, removal of garden furnitures, etc. are not uncommon in most POPS.

\section{Le Parker Meridien Hotel}

Le Parker Meridien is at West $56^{\text {th }}$ Street in Manhattan and it is a leisurely hotel with an upscale lobby. This lobby is one of the many POPS of NYC due to the agreement of the building and the city in 1970's. Even though the lobby is a privately owned public space, there is a café called Knave in this lobby with the price of $\$ 8$ for a coffee and $\$ 23$ for a cocktail. In 2015, Chaban from The New York Times decided to make a small test for the publicness of this place by bringing a pizza and some friends to hang out in the lobby. The bartender politely asked them to leave because outside food was illegal and if they wanted to eat, they had to buy from the Knave. The question of what happens to homeless residents wanting to rest in this POPS remains a mystery (Mahony, 2016).

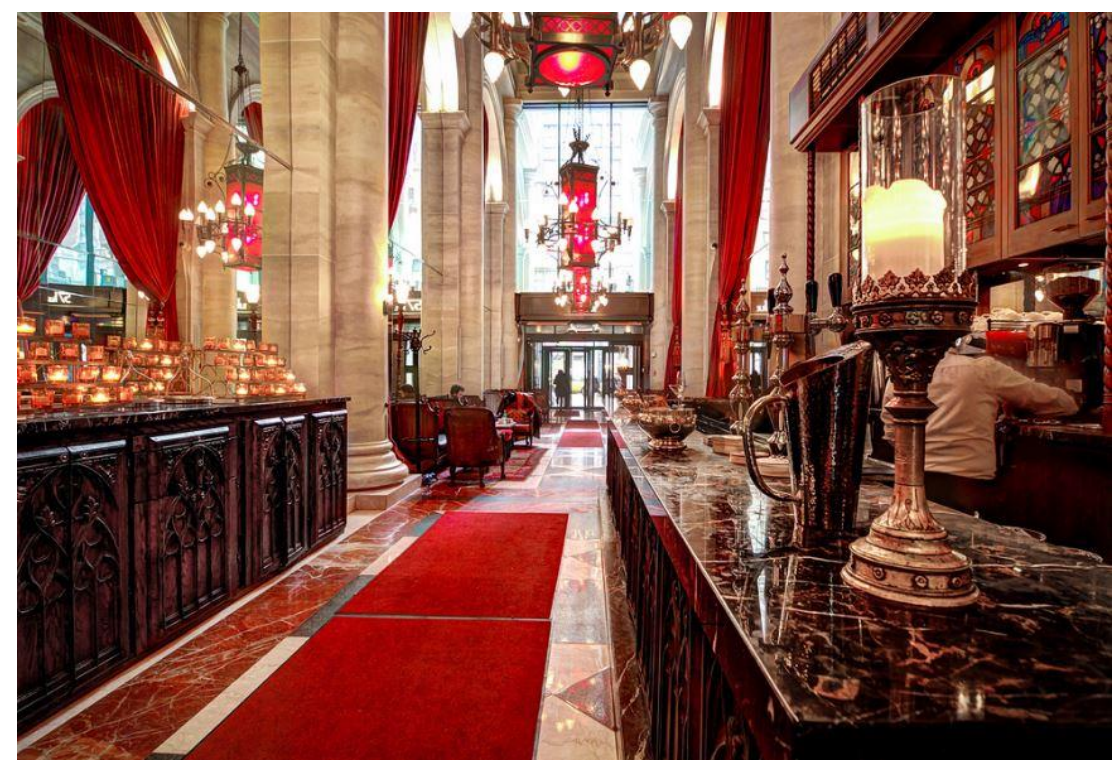

Figure 6. Le Park Meridien Lobby, Knave Cafe (Mahony, 2016).

Hotel lobbies are relatively easier urban areas to satisfy the POPS requirements due to their very nature being open to strangers. However, the above-mentioned incident shows that only passers-by are welcome in this privately owned public space. There are no other indications of being public other than the small sign next to the entrance of the lobby, not to mention the high ceiling, the concierge desk and the luxury café. It is certainly less inviting for the every day community. The inherent cruelty involved is something that affects us all, whether or not we happen to have the price of a coffee to spare by way of paying a half-hour's rent on a place to sit (Greenfield, 2013).

\section{The Effects of the Privatization of Public Space}

The goal of privatizing public space was to conserve parks and provide the residents an area for expressing themselves but the turn out of events seems like this approach is changing the notion of public space. The purpose in the beginning was to create public space for everyone, not just for the wealthy. This is a disconcerting fact given that the present economic situation of other cities is also pointing them to this direction for the maintenance of public spaces as well. To sum up, it can be stated that the privatization of public space deepens the gap between the poor and rich. big urban projects on the drawing boards in New York still tend to be the products of negotiations between government agencies anxious for economic improvement and private developers angling for zoning exemptions. 
At first glance, parks and public spaces are not strictly crucial public amenities like fire and police stations. Therefore, the government struggles to allocate funds for public spaces and gives this opportunity/duty to private organizations which lead the public spaces become luxury spaces used only by the luxury class.

Over the years, the most consistent victims of POPS have been the homeless (Mahony, 2016). The indoor privately owned public spaces generally resemble shopping malls rather than public parks. Consequently, the retail organizations renting space from these POPS are not fit with the public space character and they often see the homeless as threats to the customers. This result in efforts to push them out of the public spaces and the homeless usually rely on public space for basic functions such as eating, resting and surviving cold winter months. Those without shelter are generally considered a threat to public sometimes due to their small contribution to the consumer economy. Sometimes this is the reason behind their "removal" from the "public" atriums by the private organizations who own these public spaces.

The above examples show that POPS are supervised by more authoritative manners and they restrict the users' acts within these spaces putting an important social dimension at stake. "When space is controlled, and especially when the public is unclear about what the legal or acceptable boundaries of activity are, we tend to police ourselves, to monitor our behaviour and to limit our interactions, especially after embarrassing confrontations with security" (Garrett, 2015). Even though they are accessible and usable by public, they usually have small nuances of capitalism giving public the feeling that the privately owned public space only belongs to certain people. They use surveillance cameras, generally a security guard is present and the atmosphere is very corporate due to the architectural elements and existing logos. Additionally, POPS encourage consumption more.

According to the New York City's zoning resolution, privately owned public spaces' owners are not obliged to be detected by the government about their rules and regulations for the POPS. This means that they are almost free to do or restrict anything on privately owned public spaces decreasing their accountability. Private ownership harms the concept of public space, where a collective memory should be formed. Due to the freedom of control over public space, which is granted to private organizations, social and individual rights are destroyed. The freedom to make and remake our cities and ourselves is one of the most precious yet most neglected of our human rights (Harvey, 2008).

\section{Conclusion}

Public spaces need to be considered as philosophical entities as well as physical places. They need to be spaces of free speech, expression and gathering for the public and the public should have a say in defining the requirements of a public space. At the most basic level, if a city isn't furnished with a well-developed fabric of public spaces of different sizes and shapes and types, there is no place to simply be if you are not actively consuming (Greenfield, 2013). Public spaces should cherish cultural diversity and equity even if they use private financial means to maintain the space. Designers, architects and urban professionals need to be fair when measuring how public these spaces are. Increased control over public spaces hinders the creation of a welcoming space.

Public authorities have the responsibility to provide public spaces for the community interaction and city social life as public spaces contribute essentially to the urban quality of life. Privatized public spaces are not public any more because the government does not have a vital say in the context of public spaces. Even though there are not enough funds to create equal public spaces all over the city, the public authority should be responsible for providing public space and ideally guard them. Public spaces are too fundamental to be placed in private hands even for the sake of efficiency and capital. Private sector can also have a role in this setting but only along with public authorities and community participation.

In this situation, our cities are turning into environments of surplus only and they provide for the wealthiest and strongest. Public spaces transform into pseudo-public spaces that are actually private properties far from civic formations. Civilization means that each citizen has the right to grow and to become who they are, and it also means that the city is designed and structured in a way that helps them do so (Greenfield, 2013). People should have a right to the public space with absolute accessibility and the permission to use the space spontaneously. The Occupy protests and the APOPS are results of an emerging awareness about the fundamentality of public space. Though it is unlikely to have publicly controlled spaces rather than privately owned spaces in the near future due to the financial situation, this awareness will lead to a better understanding of the importance of public spaces when it comes to the richness of city life. 


\section{References}

[1] Blackmar, E. 2006). Appropriating 'the Commons': The Tragedy of Property Rights Discourse. In S. Low \& N. Smith, The Politics of Public Space (1st ed. ). New York: Routledge.

[2] Carr, S. , Francis, M. , Rivlin, L. , \& Stone, A. 1992). Public space (1st ed. ). Cambridge [England]: Cambridge University Press.

[3] Chaban, M. 2015). Unwelcome Mat Is Out at Some of New York's Privately Owned Public Spaces. New York Times. Retrieved from http://www. nytimes. com/2015/09/08/nyregion/unwelcome-mat-is-out-at-some-of-newyorks-privately-owned-public-spaces. html?_r=1

[4] Dimmer, C. 2013). Privately Owned Public Space: The International Perspective. In Sustainable Urban Regeneration. Tokyo: University of Tokyo.

[5] Garrett, B. 2015). The privatisation of cities' public spaces is escalating. It is time to take a stand. The Guardian. Retrieved from https://www. theguardian. com/cities/2015/aug/04/pops-privately-owned-public-space-citiesdirect-action

[6] Gieseking, J. , Mangold, W. , Katz, C. , Low, S. , \& Saegert, S. 2014). The people, place, and space reader (1st ed. ). Routledge.

[7] Greenfield, A. 2013). Public space, civilization and the self (long). Adam Greenfield's Speedbird. Retrieved 7 January 2017, from https://speedbird. wordpress. com/2013/09/22/public-space-civilization-and-the-self/

[8] Harvey, D. 2008). The Right To The City. New Left Review, 2 (53), 23-40.

[9] Helleman, G. 2016). Privately Owned Public Spaces: curse or blessing?. Urbanspringtime. blogspot. com. tr. Retrieved 6 January 2017, from http://urbanspringtime. blogspot. com. tr/2016/06/privately-owned-publicspaces-curse-or_26. html

[10] Kimmelman, M. 2012). Foreword. In R. Shiffman, Beyond Zuccotti Park: Freedom of Assembly and the Occupation of Public Space (1st ed. ). New York: New Village Press.

[11] Low, S. , Taplin, D. , \& Scheld, S. 2005). Rethinking urban parks (1st ed. ). Austin: University of Texas Press.

[12] Mahony, E. 2016). From Zuccotti Park to Trump Tower

[13] Jacobin. Jacobinmag. com. Retrieved 7 January 2017, from https://www. jacobinmag. com/2016/12/privatepublic-space-nyc-urban-politics-policy/

[14] Privately Owned Public Spaces. 2007). Www1. nyc. gov. Retrieved 6 January 2017, from https://www1. nyc. gov/site/planning/zoning/districts-tools/private-owned-public-spaces. page

[15] Purcell, M. 2003). Citizenship and the right to the global city: reimagining the capitalist world order. International Journal Of Urban And Regional Research, 27 (3), 564-590. http://dx. doi. org/10. 1111/1468-2427. 00467

[16] Rosenberger, R. 2016). Trump Tower and the Question of 'Public' Space. The Atlantic. Retrieved 7 January 2017, from http://www. theatlantic. com/business/archive/2016/08/trump-tower-and-the-question-of-publicspace/494027/

[17] Ulam, A. 2013). Our Parks Are Not for Sale: From the Gold Coast of New York to the Venice Biennale. Dissent, 60 (1), 64-70. http://dx. doi. org/10. 1353/dss. 2013. 0021

[18] Wilshire, L. 2012). Public Space in New York \& London. Retrieved 6 January 2017, from http://www. leewilshire. com/public-space-in-new-york-london/

[19] Woodward, D. 2012). Zuccotti Park Restrictions. Retrieved from http://urbanomnibus. net/2012/05/rules-ofconduct/ 